\title{
Faculty Status and Librarians: The Rationale and the Case of Illinois
}

\author{
Robert G. Sewell
}

Faculty status for librarians was widely promoted during the late fifties and sixties; the topic is still discussed extensively in the literature. Many library administrators and librarians are of the opinion that the faculty model is inappropriate for academic libraries. Some libraries have persisted in the implementation of full faculty status. They have found the principles of collegiality, academic freedom and tenure, and the concept of the librarian as teacher and researcher to be viable and highly beneficial to the academic library environment. One such library is the University of Illinois at Urbana-Champaign Library.

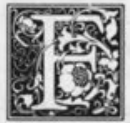

aculty status for librarians has been widely discussed in library literature, especially in the last two decades. ${ }^{1}$ It is a matter which addresses fundamental issues in librarianship, especially in the areas of professional development and the managerial structure of academic libraries. The bold and optimistic statements of library proponents of faculty status in the late fifties and sixties are not as frequently found in recent articles and monographic studies on the subject. In fact, a rather melancholy tone has set in. On the one hand, the fact that librarians in colleges and universities have not yet achieved equality with the teaching faculties of their institutions has been a source of lamentation. On the other hand, there has been great controversy and anxiety among librarians over meeting faculty standards and responsibilities. What has prolonged the implementation of faculty status and caused this anxiety, I believe, is that librarians did not fully anticipate what they were getting into.

When the Committee on Academic Status of the Association of College and Re- search Libraries formulated the principle in the late fifties that academic librarians take on the academic viewpoint, the full implications of this principle were not realized. According to the Committee, this viewpoint implied that "Professional librarians must accept in principle the standards, customs, and regulations governing the faculty of their institutions. ${ }^{\prime 2}$ The major reasons librarians seek faculty status are: to improve the stature of the profession and their own status within their academic community, and to receive the full benefits of the teaching faculty including higher salaries, sabbatical leaves, and more freedom and autonomy. What the commitment to faculty status meant in terms of adopting faculty roles and standards of evaluation had not been clearly recognized. Many librarians have found themselves ill-prepared for their duties as faculty. University and library administrators frequently have difficulties in finding common ground for determining the proper roles and responsibilities for the librarian who is also a faculty member.

Many academic libraries have now settled for something less than "faculty sta-

Robert G. Sewell is West European acquisition coordinator and associate professor of library administration, University of Illinois at Urbana-Champaign. 
tus." They have opted for "academic status." The terms "academic" and "faculty" have often been confused and used interchangeably in past discussions of the status issue. But recently, the two terms have been distinguished from one another. ${ }^{3}$ With faculty status, or full faculty status as it is sometimes referred to, librarians accept all the rules, regulations, procedures, and benefits of the teaching faculty in a strict sense. Academic status classifies librarians as academic staff rather than faculty, administrative personnel, civil service, or some other category. With academic status, librarians enjoy some, but not all of the privileges of the teaching faculty, but do not hold faculty rank. Instead, they establish their own ranking system and criteria for evaluating their own work. The major reason for accepting something less than full faculty status is to avoid being evaluated in the same manner as the teaching faculty. In this scheme, librarians prefer not to be thought of as teachers and researchers, thereby reducing the emphasis on research and publication. Two prominent models of academic status for librarians are the California State Universities ${ }^{4}$ and Columbia University. ${ }^{5}$

Thus, while there are many college and university libraries that have academic status and/or quasi faculty status, very few have attempted to implement full faculty status. One which has is the university library at the University of Illinois, Urbana-Champaign, hereafter referred to as UIUC. It is, I believe, one of the most committed to the concept of librarians as faculty and has done more than most academic libraries in the country to implement the concept. The objectives of this paper are to describe the rationale for faculty status for librarians and to illustrate how UIUC has dealt with this issue.

\section{THE RATIONALE}

There are three general principles which are key to the concept of a faculty. They are: (1) academic freedom and tenure; (2) collegial governance; and (3) standards for evaluating a professor's work.

Academic freedom and tenure refer to the principles of freedom of the profes- sional from outside interference with professional judgement, and of the granting of tenure, to protect that freedom, after a peer review of competence. Collegial governance relates to faculty participation, influence, and control in administering the college or university. The standards for evaluating a faculty member's work generally involve three areas: teaching, research, and service. After the initial educational background and experience are decided upon for appointment at the assistant professor level, promotion to associate professor and the granting of tenure require clear evidence of the potential of the individual for "national and international recognition" in one's field. The rank of full professor is granted when that recognition can be demonstrated to have been achieved.

These three interrelated principles are the foundation of the faculty ethic. In a field where the bureaucratic and hierarchical pattern of management has been the norm, and the distinctions between clerical and professional tasks were, and often are, blurred, librarians have had to make some radical changes to become part of the faculty. How this is best accomplished has been a central dilemma for the profession. The discussion that follows focuses on librarians in large, researchoriented institutions of higher education.

\section{Librarian as Teacher}

If librarians are to become part of their institution's faculty, the case must be made that their work is comparable to that of the teaching faculty. In a university the primary area of responsibility of the faculty is teaching, although research often, in fact, takes precedence. Do librarians teach? Teaching imparts knowledge to others. A teacher in a university has the freedom and responsibility to select the course materials and present the subject in a manner deemed most suitable. This is a creative and independent activity. Librarianship is a more closely guided and controlled activity than is teaching. Even when dealing in strictly professional duties, librarians follow rules, schedules, and routines. While teachers may be keenly aware of student FTEs and the size 
of their teaching load, the nature of teaching is not as easily quantified as is the number of books and serials selected, ordered, and cataloged, or the number of reference questions answered. Often specific quotas are imposed in work involving technical processing. On the whole, the work of a librarian is far more concrete than that of a teacher. How library work is done, however, does involve a large degree of latitude in, for instance, the interpretation of cataloging rules, selection of materials, and in formulating new policies. All this requires professional judgement for which the individual is accountable. Furthermore, the whole enterprise of librarianship can be seen as a transfer or communication of knowledge from the librarian to the user. An analogy can thus be drawn with the teacher-student relationship. Furthermore, librarians often do directly teach students in such areas as bibliographic instruction, term paper counseling, and research consultation. Some librarians do classroom teaching in their specialty, even outside library science.

Since librarians have often thought of themselves and have been regarded as servants of their " patrons," especially the teaching faculty, it may be hard for some librarians and the teaching faculty to view each other as colleagues. But when their basic goals are recognized to be complementary, a positive and new dynamic interaction can occur between the librarians and the teaching faculty.

\section{Collegiality}

Librarians' participation on university committees and the faculty senate can foster this interaction, increase the awareness of librarians to university-wide issues, and thereby improve their effectiveness as librarians and faculty. This participation in the governance of the university is an important element in faculty status for librarians. So too is the implementation of such patterns of governance into their library structures.

When librarians think of each other as colleagues, rather than as elements in a hierarchy, they can deal with each other as equals and develop a collegial governance structure. This has emerged in one form or another in many academic libraries and is a general reflection of trends in institutional management throughout contemporary society. The standard reason given in the literature of management for greater democratization in the decision-making process is that it increases efficiency when those closest to the problem and those who will have to implement new policies participate in finding solutions.

Much of the discussion in library literature in this area has been under the rubric of decision sharing and participative management rather than as collegial governance. It is still widely felt in the profession that in administrative structure, libraries resemble hospitals more than universities. ${ }^{6}$ Like hospitals, the argument goes, libraries are service organizations and are composed of large work forces ranging broadly in status. Contrarily, in the organization of a college, independent and autonomous professors come together as equals to determine how to run their departments and general campus affairs. The conclusion of this argument (with which I disagree) is that the faculty model of governance is not appropriate for libraries.

\section{Faculty Control vs. Administrative Control}

While there is some truth to these views, they are based on a misconception about the nature of collegial governance by the teaching faculty. Since teaching faculty must also work within an administrative structure, the control of their affairs is by no means absolute. In fact, it can be stated that, while democratization within academic libraries is generally increasing, the expanding role of university administrators is greatly eroding the teaching faculty's independence. In a report on faculty participation in academic decision making it was stated:

The organizational arrangements through which faculties have traditionally participated in decisions no longer seem to secure the desired degree of participation, and dissatisfaction with what some members of the professoriate view as their increasingly secondary role appears to be growing. The more mordant crit- 
ics have become outspoken in denouncing the "bureaucratization" of today's colleges and universities, what they perceive to be "administrative arbitrariness," increasing reliance on the supposed legerdemain whereby, it is argued, mock recognition is given to faculty participation in decisions.?

These complaints are particularly strong in large universities where the complexity and size of problems have increased and the administrators are more remote from the faculty. In truth, there was never a golden age of faculty rule and always a tension between faculty and administration. In an extensive study, The Faculty in University Governance, it was asserted, "The basic dilemma in the university is the appropriate balance between bureaucratic structure and formal authority, with their emphasis on accountability and rationality, and functional authority and collegial organization, with their stress on informality. In other words, the dilemma is between power and influence. ${ }^{\prime 8}$ The statement applies equally to academic libraries.

McConnell and Mertimer specified several areas in which faculty have effective control. They are academic affairs, the education and certification of entrance to the profession, staffing of graduate programs, establishing requirements for degrees which become prerequisites for faculty employment, selection of faculty members, determination of criteria for appointment, promotion, and tenure, virtual immunity from evaluation external to the profession, setting one's own work schedules, and control over what they teach.' Those activities dealing with formal aspects of the educational process have no clear analogy with librarian's work. Some librarians, however, serve on accrediting committees for library schools and on staffs of library schools. So, there is the possibility for practicing librarians to exert some influence on certification and degree requirements for library science degrees, but this does not occur as a rule.

All the remaining areas regarded as within the realm of faculty control are, or should be, true for librarians with faculty status. Through participation on search committees, librarians select their col- leagues and determine the requirements for employment. Faculty establishment of criteria for appointment and evaluation of professional work is a vital element of faculty status. The establishment of such criteria by library faculty, however, is not necessarily free from all outside pressure when the university administration is involved in the promotion procedure, usually as the last step in the review. If academic librarians do not have standards similar to that of the teaching faculty, their recommendations for promotion may be rejected at that level. I will expand on the question of criteria later.

In libraries where librarians have faculty status, the peer review process for promotion should follow the faculty model. The major services, usually technical and public, are organized as faculty departments. The advisory committees, which are elected from the respective departments, review their fellow professionals' work according to established criteria. Their recommendations for promotions are forwarded to the head of their department (the director of the service), who in turn sends lists of names for promotion to the dean of the college (the university librarian) for approval. In the last stage, a campus-wide committee makes the final decisions.

The matter of faculty setting their own work schedules has been extremely controversial for librarians. Both library administrators and librarians themselves have had difficulty in breaking out of rigid time schedules. There are many new patterns emerging, which I will discuss in some detail later. But this is one area where librarians have had difficulty in gaining control.

The last item in the list of faculty control is the determination of what they will teach. For the librarian, this means professional control and autonomy in performing one's duties. For instance, for catalogers, no revision of their work should be necessary after a period of probation. A bibliographer has the freedom and responsibility to select materials in a manner the individual determines to be most effective. Of course, to work in total isolation would be foolish and probably impos- 
sible. Furthermore, this concept of autonomy presumes a high level of professional achievement, as well as an effective and democratic means of review and evaluation of the profession's work at annual periods.

\section{Criteria for Evaluation}

Standards by which a librarian's work is judged may be the most disagreed upon aspect of faculty status for librarians. If librarians accept faculty status, they should adhere to the criteria of the teaching faculty with only minor modifications. In the past, libraries which granted faculty rank appointed, as a rule, new librarians at the rank of instructor and usually granted tenure at that rank or at the rank of assistant professor. Only those with substantial administrative responsibility gained the ranks of associate professor or professor. This is clearly not the normal pattern of the teaching faculty and is a tacit recognition that librarians have not been able to meet the criteria which obtain for the rest of the faculty. But in recent times there has been increasing pressure from university administrators to bring librarians with faculty rank in line with the general standards for promotion and tenure.

Librarians do begin with a major handicap, because the usual professional degree required for entrance in the field is a master's degree in library science. Besides not meeting the standard requisite Ph.D. degree for teaching in a university, MLS programs do not, in most cases, train students to conduct research, now a fundamental requirement for the academic librarian. This condition puts the librarian at a disadvantage when trying to "publish or perish" in six years or less. Many librarians, however, have been able to cope with this problem and become actively involved in the publication of their research. ${ }^{10}$ Librarians who have done research and published find it a rewarding and important role in their professional development. It provides a means of advancement in professorial rank and merit salary increases outside the administrative hierarchy. Research allows librarians to reflect on and even find solutions for problems in their work as well as stimulate creative thought in general. Publication is one aspect of the development of a national reputation. The other aspect is service to the profession by participation in national organizations. These two activities are often complementary and nurture each other: when one publishes, one becomes known and is asked to join committees; when one is known from committee work, one is invited to write papers. Thus, publication and service to the profession lead to greater visibility and a national reputation, which is the basic criterion for advancement to the associate or full professor ranks.

\section{THE CASE \\ OF THE UNIVERSITY OF ILLINOIS AT URBANA-CHAMPAIGN LIBRARY}

The means by which librarians achieve full faculty status are neither easy nor quick. They do not evolve from a spontaneous and universal welling up of sentiment from librarians and their administrators. They usually come about when librarians hold faculty rank, but are not organized like the rest of the faculty, nor do they meet their standards for promotion. University administrators demand that librarians become a true faculty or lose their status. Thereafter, it takes a library administration willing to implement policies that will enable librarians to become faculty, and sufficient, if not total, support of the academic librarians for faculty status. I will now describe some of the major events in the progress toward full faculty status at the UIUC Library from 1970 to the present, and enumerate some of the specific policies that have been instituted to further the cause of faculty status for the librarian.

\section{From Downs to Atkinson}

Librarians at the UIUC have had a long tradition of holding faculty rank. Robert Downs, the dean of the library from 1943 to 1971 , was one of the most outspoken advocates of faculty status throughout his career. It was largely because of his prestige and influence in the university that librarians held faculty rank. During his 
term of office, the term "with rank of" was affixed to the professional rank and job title, e.g., "classics librarian with rank of assistant professor." Aside from professorial rank, however, very little of what is thought of as essential to faculty status prevailed in the library. Virtually all important and professional decisions emanated from the top. There was little autonomy for the individual librarian and little opportunity or encouragement for librarians to do research or participate in national professional organizations. In spite of this stifling atmosphere, a few librarians did manage to publish and were rewarded for their efforts. These cases, however, were rare. Most librarians were granted tenure at the rank of instructor or assistant professor with associate professor and professor ranks reserved for administrative personnel. The pattern of bureaucratic and hierarchical management was still widespread in the library world during Downs' tenure. But pressures for change were building up during the last few years of Downs' administration.

In 1970 the vice chancellor for academic affairs and the campus committee on promotions and tenure expressed difficulty in evaluating, and dissatisfaction with, the recommendations for promotion with tenure from the library, as well as from the college of education, agriculture, and engineering. These four units of the university lacked well-defined standards outside traditional academic areas and were singled out as relying too heavily on a local "service" criterion for recommendations for promotion. There was also growing dissatisfaction among librarians with the lack of opportunities for professional development and of democratic procedures within the library system.

After Downs' retirement, the demands for change became more vocal. One can best describe the period from 1972 to 1976 as a transitional period leading up to the selection of Hugh Atkinson as university librarian. During that period, the director, Lucien White, and after his untimely death, the acting director, Robert Oram, made some positive steps in the direction of faculty status. One of the first moves made by White was to drop the now dis- credited term "with rank of" suffix to the librarian's job title, and add the phrase "of library administration." Librarians then had a job title and a separate rank, e.g., "classics librarian and assistant professor of library administration." Funds for research and travel became available and were distributed fairly widely; committees staffed by librarians throughout the library proliferated, allowing for more participation in decision making. In 1975 an elected Promotion and Tenure Advisory Committee was established to begin the process of peer review, and in the same year a statement of criteria was written by the Appointment, Promotion, and Tenure Committee.

Two areas of library policy regarding promotion and tenure continued to be designated problems by the vice chancellor for academic affairs: the library's reluctance to adopt the "up-or-out" policy of making a tenure decision and promotion to associate professor after six years, and the "too modest" criteria for granting tenure without promotion. In a memo dated May 3, 1976, to Robert Oram, acting director of the library, from Morton Weir, vice chancellor for Academic Affairs, concerning the library's statement on appointment, promotion and tenure, it was stated that the library's requirement for excellence in only one of the three areas of teaching, research, and service was not enough for granting tenure. The memo went on to state:

If such modest criteria are adopted, there will continue to be a wide gulf between the requirements for members of the faculty in the Library and those in other units. As you may know, there is increasing criticism of what some call the "double standard" we have been using: one set of stringent criteria for faculty in teaching units and another, much less stringent set for those in the Library. As our application of the criteria for candidates from teaching units becomes increasingly demanding, I expect that there will be increasingly strident calls for closer correspondence between the criteria used in the Library and those in use in other units.

It was clear at that time that the library was under a threat to bring up standards or lose faculty status. In spite of the advances that had been made, the library ad- 
ministration was reluctant to go much further in tightening standards and loosening administrative control of the library. It felt that it was unfair to evaluate people by new standards which they did not know they would have to meet when hired. In addition, most of the library administration at that time had cut their professional teeth under Downs' leadership, and found it difficult to completely reorganize the library along faculty lines.

\section{Hugh Atkinson, University Librarian}

In 1976 Hugh Atkinson was appointed UIUC university librarian. He was known for his strong commitment to faculty status at Ohio State. In a short time he brought in new administrators with views similar to his. The technical and public services were organized on a departmental basis with the directors also acting as department heads. Each service now has an advisory committee to serve as a peer review group for salary increases and promotion and tenure decisions. Standards for promotion and tenure have been made more rigorous with excellence being required in the areas of primary job responsibility (equated with teaching), and research and publication, and to a lesser extent service. During the last five years, all appointments for tenure track positions have been made at least at the assistant professor level, and the six-year upor-out rule has gone into effect, although some appointed more than five years ago still have gained tenure at the assistant professor level. In the 1980 academic year several of the first people hired at the assistant professor level have been granted tenure and promoted to associate professor simultaneously.

\section{Eighteen Policies Related to Faculty Status}

There have been many innovations to encourage professional development which are now in effect, some of which were begun before Atkinson's tenure. They represent, I believe, some of the benefits and functioning of faculty status in a large research library. A good way to get at these policies is to respond to a questionnaire designed by Stella Bentley which lists eighteen items and provides a checklist of specific policies related to faculty status. ${ }^{11}$ I will answer each question about these policies as they pertain to the UIUC Library and offer further commentary where appropriate. Before doing so, however, the following figures about the staff at the UIUC Library are presented to put this information into perspective. In 1982 there were 119 librarians with faculty rank: 15 professors, 34 associate professors, and 70 assistant professors. None had the rank of instructor. The FTE nonprofessional staff numbered 296 and there were 109 FTE students. It is within this context that I will discuss the eighteen policies related to faculty status.

1. Source of faculty privileges-These privileges derive from librarians holding faculty rank and status.

2. Eligible to vote on library committeesAll librarians in tenure track positions can vote on library committees.

3. Eligible to vote on faculty committeesAll librarians in tenure track positions can vote on faculty committees.

4. Eligible to serve on library committeesAll librarians in tenure track positions can serve on library committees. There are sixteen standing committees in the library with 100 seats which currently are held by seventy different librarians. These committees consist of two faculty advisory committees and various committees dealing with faculty governance, administration, research, and policy.

5. Eligible to serve on faculty committeesAll librarians in tenure track positions are eligible to serve on faculty committees. For instance, there are eleven permanent library seats on the UIUC senate and currently ten positions on various senate committees are held by librarians. Librarians also serve on such campus committees as Facilities Planning Committee, and Faculty Advisory Committee.

6. Eligible for sabbatical leave-Librarians were technically eligible for sabbatical leaves, even during the 1950 s and 1960s, but only a small number took advantage of this right. Before the last decade librarians 
were generally not encouraged to take sabbaticals or even made aware of the possibility.

7. Received sabbatical leave-In the last ten years, approximately forty librarians have taken sabbatical leaves.

8. Release time for research-In general, this concept does not pertain to UIUC. Since research, along with other professional activities, is considered part of the job, one does not need to be released from one's duties to pursue research. (The nature of the work schedule at UIUC will be explained more fully later in this article.) However, when a person needs time for a long and concentrated effort to complete a research project, informal arrangements for research leave ranging from one to several months can be made with the director of the faculty member's service. In the last five years over a dozen such arrangements have been made.

9. Computer time for research; 10. Travel expenses for research; and 11. Financial support for research-Library faculty have equal access to campus-wide research funding as well as to internal sources. The Library's Research and Publication Committee was established in 1972 to offer advice on research and possible alternative funding sources, as well as to give direct grants-in-aid for research projects. The committee members are appointed by the university librarian and the major source of funding is from overhead cost monies from numerous outside grants to the library, especially from the National Endowment for the Humanities and the Office of Education. In addition, the university librarian supplements this varying amount with money from discretionary funds. In the last five years, the committee's annual budget has been approximately $\$ 15,000$, with twenty to forty awards granted each year. The committee decides on a competitive basis which proposals to support. Grants have been given for research travel, photocopying, editing, art work, graduate assistants, student wages, and computer time.

Computer time, in general, is available to all members of the library faculty in the following amounts: a base of 10,000 SRUs with an additional 3,000 SRUs each week up to a maximum of 20,000 per week. If a larger block of computer time is necessary, library faculty can present grant proposals to the Research and Publications Committee, the campus-wide Research Board, and to agencies and foundations outside the institution.

The Research Board, an executive committee of the graduate college, supports research activities of the UIUC faculty. In the last five years there have been twentyfive Research Board awards made to members of the library faculty amounting to approximately $\$ 40,000$. Most of these grants have supported research travel. Librarians have also received research funding from teaching departments that they serve, as well as from such agencies as $\mathrm{Na}$ tional Endowment for the Humanities and the Japan Foundation.

In addition to research support, librarians also have access to travel funds for convention expenses. The two services had travel funds amounting to $\$ 20,000$ in 1982. These funds are allocated by the services' elected Advisory Committees. Grants are awarded to individuals according to specific guidelines related to the degree of participation at a conference. Librarians can also apply to the Research Board's Scholar's Travel Fund for convention travel if they are presenting papers at major conventions and the applicant's department has put up seed money. If these two criteria are met, the amount of the grant is based on how distant the convention is from the university.

12. Length of contract-The norm is still the eleven-month contract. Nine-month contracts are possible and at present four librarians have them: the geology librarian, the classics librarian, a reference librarian, and an assistant education librarian. Most librarians are discouraged by the $2 / 11$ cutback in salary required with a nine-month contract. This is an area where the library faculty is far behind the teaching faculty. Librarians' salaries fall within the ranges of the various professorial ranks. However, the librarians are usually lower in the ranges and are being paid for two months more work. For in- 
stance, at initial appointment the assistant professor of library administration in 1981 was usually paid $\$ 13,500$, whereas the assistant professor in the humanities, the lowest paid teaching faculty, received at the very least, $\$ 17,000$ for two months less work. If the library faculty must meet similar standards for promotion and tenure, their compensation must be brought up to that of the teaching faculty.

13. Satisfaction with academic statusSince I have not conducted a survey of the library's faculty, I cannot make a definite statement on this matter. Clearly there are some who dislike the system and are uncomfortable with it. However, most would not want to give up faculty status and many truly thrive on it.

14. Criteria for promotion-performanceExcellence in performance is essential for promotion because without it, no further consideration can be made for promotion. According to the April 1981 "Statement of Criteria and Procedures for Faculty Appointment, Promotion, and Tenure, and Termination" for the UIUC Library, "In the University Library, the primary criterion for evaluating librarians is excellence in librarianship. Excellence must be amply documented in the individual's annual evaluations . . . and in the [librarians' personal] annual reports."

15. Criteria for promotion-researchResearch in progress is considered for merit increases, but the research must be published for promotion.

16. Criteria for promotion-publicationPublication is definitely required for promotion and tenure. The UIUC Library faculty is very active in publishing its research. The last systematic count of library faculty publications was taken in 1979. During that year librarians published nine books, twelve chapters in books, fifty-five articles, forty-two book reviews, and three technical reports. In addition to publishing articles in such library journals as American Libraries, College $\mathcal{E}$ Research Libraries, Law Library Review, Library Journal, Library Quarterly, Journal of Library History, and Reference Services Review, librarians' articles were published during that year in American Historical Re- view, Byzantine Studies, The Classical Journal, Denver Quarterly, Journal of Medieval and Renaissance Studies, Journalism Quarterly, Slavic Review, and Women's Studies International Quarterly. All indications are that the current rate of publication surpasses that of the 1979 level.

17. Criteria for promotion-professional activities-These activities are part of the overall picture of a librarian's accomplishments, and should exist at least on a regional level, and preferably on a national level.

18. Criteria for promotion-second master's-A second master's degree or $\mathrm{Ph}$.D. are taken into consideration for promotion, but acquiring these degrees does not automatically guarantee promotion.

In general, promotion at the UIUC Library requires that an individual present a whole configuration of accomplishments, separate from administrative responsibilities. As stated in the previously mentioned April 1981 "Statement of Criteria,": "It is the policy of the University Library that level or scope of administrative responsibility shall not be a criterion for advancement in rank." The general criteria for all faculty at UIUC, including librarians, are as follows:

Scholarship, resident instruction and continuing education, and service to the public and the University are all important factors. . . . Realistically, we cannot expect every faculty member to perform outstandingly in all of these functions. We therefore operate on a compensatory system where some weakness in one area may be offset by particular strength in another. But when the important aspect of the creation of new knowledge-whether by research or scholarship, or creative artistry-is generally weak or virtually absent, a question must be raised as to whether promotion or the awarding of indefinite tenure is in the best interest of the campus.

\section{Work Schedule}

One policy which has been established at the UIUC Library, but was not fully discussed in the above eighteen points, concerns the work schedule. It represents perhaps the most dramatic change in attitude of the library over the last ten years. In 1970 the work schedule was 8:00 to 
5:00, with two fifteen-minute breaks, and one hour for lunch. In addition, one hour per week was allowed for personal business. When the demands for research and professional involvement increased in the mid-70s, a different schedule was established: thirty hours per week for "library work" and ten hours for professional development, primarily research. There was great controversy over whether committee work was library work or individual professional development. In the last five years, however, the defined and explicit work week has been abolished.'The librarian, as faculty member, is allowed to determine his or her own work schedule in consultation with the department head. This innovation is not "flextime," which has been introduced to many businesses and industries, but follows the general faculty pattern. In an article published in The Chronicle of Higher Education (May 11, 1981), "How Not to Measure What a University Does," John Shelton Reed stated, "No academic worth a damn works or thinks in 9-to-5 terms. . . . For any selfrespecting academic, the line between on and off the job is not all distinct ... professors often (speak) of looking forward to vacation so they can get work done." Since professional development in such areas as research, publication, and committee work is now seen as part of the librarian's work, librarians must determine for themselves how to balance their responsibilities. While not as flexible as the teaching faculty's work, there is an ebb and flow to the librarian's work as well. While some work requires close proximity to library records, other tasks may need seclusion and distance from the library. Various work patterns have emerged. Some librarians have set up hours when they are available for consultation; some work in the evenings and on weekends, or before the library is open to the public. Reliance on the computer for holdings information and acquisitions records has enabled people to work at odd hours, since there is access to records at times when paper files are not accessible. Although the work schedule has relaxed, the total number of hours worked by librarians has, through personal commitment rather than administrative coercion, increased in most cases far beyond the forty-hour work week.

\section{Flexibility}

The use of computers and the ability to determine one's work schedule are not particularly significant in themselves for faculty status. What is important is that they represent flexibility, a mentality of great significance to both faculty status and the running of large academic libraries in the contemporary world. Librarians must constantly adjust to new conditions-shifts in educational policies and curriculum, new research trends, developments in technology, and economic, political, and social changes. The professional staff of an academic library should be able to react thoughtfully and with reasonable speed to the ever-changing environment. Librarians involved in their university community, research, and professional activities, are better able to confront their library work than those who remain insulated within their own libraries. The benefits of faculty status accrue not only to individual librarians, but also to their libraries and universities.

It is difficult to measure the benefits quantitatively, but from an analysis of the 1981-82 ARL statistics some encouraging indications are evident. One can construct a library efficiency ratio on the basis of the number of volumes added per staff member. In 1981-82 the 517 UIUC staff, of whom 112 are FTE professionals, added 172,676 volumes, or 334 volumes per staff member. No other academic library of comparable size can match this rate of production. In libraries of similar stature which do not have faculty status, the ratios are the following: Yale added 262 volumes per staff member; Michigan, 221; Harvard, 200; and Columbia added 185 volumes per staff member. The UIUC Libraries' efficiency cannot solely be attributed to faculty status; automated systems and a highly productive support staff certainly play a large part in this. But, the intelligent use of staff and computer technology is dependent upon good 
administration through a flexible and alert professional staff. Faculty status has not brought the UIUC Library to a standstill. Quite the contrary. As Professor Richard L. Merritt, chairman of the Political Science Department at UIUC stated in an internal memo of 28 January, 1983, concern- ing the ARL statistics, "Illinois gets more library for its dollars or staff size than practically any of the other fourteen leading university research libraries. The university library is one of the biggest bargains in higher education!"'

\section{REFERENCES}

1. The most comprehensive review of the literature on faculty is Virgil Massman's Faculty Status for Librarians (Metuchen, N.J.: Scarecrow Press, 1972). A collection of relevant articles is Lewis C. Branscomb, ed., The Case for Faculty Status for Academic Librarians (Chicago: American Library Assn., 1970). There have been numerous articles on the subject since these two books were published, most prominently in College \& Research Libraries and the Journal of Academic Librarianship. A relatively recent survey of faculty status in libraries is Stella Bentley's "Collective Bargaining and Faculty Status," Journal of Academic Librarianship 4:75-81 (May 1978).

2. Arthur M. McAnally, "Privileges and Obligations of Academic Status" in The Case for Faculty Status, p.1.

3. For a full discussion of the confusion and eventual distinction between "faculty" and "academic" status, see Massman, p.11-21.

4. See "The Status of California State College Librarians" in The Case for Family Status, p.88-94.

5. Frederick Duda, "Columbia's Two-Track System," College \& Research Libraries 41:295-304 (July 1980). While "two-track system" usually refers to a system of defining some librarians as faculty and others as nonfaculty, Columbia's system refers to two modes of professional advancements, one through administrative "position" and the other through professional "rank."

6. See for instance Louis Kaplan's "Literature of Participation: From Optimism to Realism," College \& Research Libraries 36:473-79 (Nov. 1975) and "On Decision Sharing in Libraries: How Much Do We Know?" College \& Research Libraries 38:25-31 (Jan. 1977).

7. Archie R. Dykes, Faculty Participation in Academic Decision Making: A Report of a Study (Washington, D.C.: American Council on Education, 1968), p.v.

8. T. R. McConnell and Kenneth P. Mortimer, The Faculty in University Governance (Berkeley: Center for Research and Development in Higher Education, University of California, 1971), p.3-4.

9. Ibid., p.1-2.

10. See Paula Watson, "Publication Activities among Academic Librarians," College \& Research Libraries 37:375-84 (Sept. 1977).

11. Bentley, p.78. 